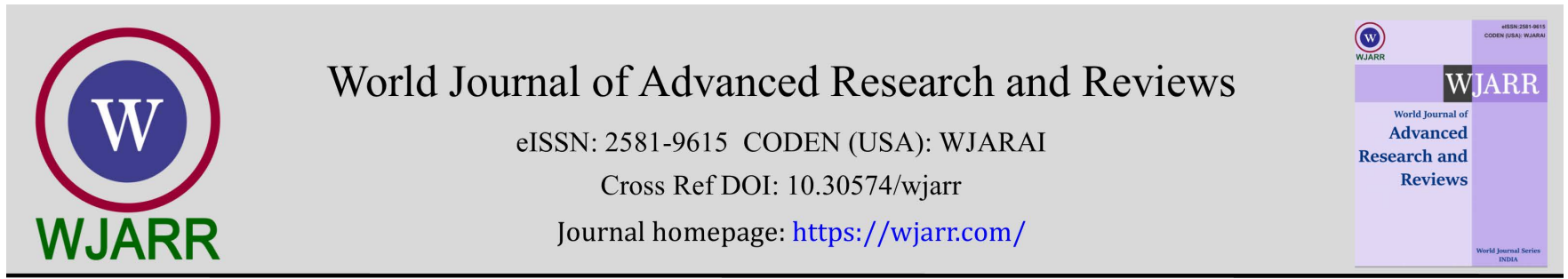

(RESEARCH ARTiClE)

Check for updates

\title{
Risk assessment of pesticide residues in water samples from river Gongola, Adamawa state, Nigeria
}

Otitoju Olawale, Moses A. Abah *, Otitoju T. Grace, Bilyaminu Habibu, Emmanuel C. Okoli and Patience U. Omajali

Department of Biochemistry, Federal University Wukari, Taraba State, Nigeria.

World Journal of Advanced Research and Reviews, 2022, 13(01), 424-432

Publication history: Received on 06 December 2021; revised on 12 January 2022; accepted on 14 January 2022

Article DOI: https://doi.org/10.30574/wjarr.2022.13.1.0015

\begin{abstract}
Pesticides used in agricultural fields pose harmful effect to non-target organisms such as humans and many other aquatic and terrestrial organisms either directly or indirectly especially when they find their way into water bodies. This study is aimed at conducting a risk assessment of pesticide residues in water samples from River Gongola, Adamawa State, Nigeria. Samples were collected randomly from different points along the river. Water samples were collected by lowering pre-cleaned plastic bottles into the bottom of the water body, $30 \mathrm{~cm}$ deep, and allowed to over flow before withdrawing. Sampling points were approximately $50 \mathrm{~m}$ away from each other. Pesticide residues in the collected samples were determined using GC/MS analysis with helium gas as a carrier. The levels of pesticides detected were compared with the maximum residue levels (MRL), the estimated daily intake (EDI) and health risk index (HRI) of each pesticide residue. Results of the analysis revealed nineteen (19) different pesticide residues belonging to organochlorines, organophosphates and pyrethroid class of pesticides. The concentrations of the pesticide residues detected in the water samples occurred below the maximum residue levels but above the acceptable daily intake set by European Union. The health risk index of each pesticide residue detected was below 1 . Hence, life time consumption of water containing these pesticides poses no significant health threat. However, the presence of banned organochlorine pesticide residues is a cause for alarm.
\end{abstract}

Keywords: River Gongola; Risk assessment; Pesticides; Pesticide residues; Maximum residue levels

\section{Introduction}

The use of pesticides in modern agriculture is the most common plant protection method for growers, owing to their fast effective nature. Several hundred pesticides of different chemical nature are currently used for agricultural purposes. Because of their wild spread use, they are detected in various environmental matrices, such as soil, water and air [1]. It is an undisputed fact that pesticides are essential in modern agriculture. There is, however, growing concern about possible environmental contamination from agrochemicals, runoff from agricultural systems, disposal of outdated stocks, containers and packets and discharge of waste from industries [2,3]. These compounds when discharged into aquatic system, plays an important role in contaminating such systems. Atmospheric transport also represents an important source of pesticides residue accumulation in water bodies. It has been recognized that the persistent and bioaccumulation tendency of these substances, their metabolites and residues in the environment make them not only remain where they are applied but instead partition between the major environmental compartments in accordance with their physicochemical properties and may thereby become transported several kilometers from the point of their original release $[4,5]$. Sediment serves as a habitat for benthic biota (such as insects and clams, which are commonly consumed by fish), as both a source and a removal mechanism for some contaminants to and from the stream

\footnotetext{
*Corresponding author: Moses A Abah

Department of Biochemistry, Federal University Wukari, Taraba State, Nigeria.

Copyright (@ 2022 Author(s) retain the copyright of this article. This article is published under the terms of the Creative Commons Attribution Liscense 4.0.
} 
and as a vehicle for contaminant transport downstream [6]. Aquatic biota also is important in the food web of terrestrial organisms, with some aquatic biota, such as fish, being consumed by people and wildlife [7].

Surface and ground water bodies are easily being contaminated by runoff water or by rain for the indiscriminate use of pesticide. According to [7], the widespread use of pesticide may contaminate the environment and freshwater fish. It is obligatory of entering the fractions of applied insecticides into the aquatic ecosystems due to the application techniques for crop protection. From water bodies, pesticide residues directly or indirectly pass through the food chain and eventually cause harm to human and other aquatic or terrestrial organisms [6]. Several problems can be caused in human body due to pesticide exposure $[5,8]$. Organophosphorous pesticides (OP) may affect sperm chromosome segregation and augment the risk for genetic syndromes [9]. [10] Reported an association between chlorpyrifos use and incidence of lung cancer in Iowa and North Carolina. [11] Observed the association of soft-tissue sarcoma with specific pesticides such as aldrin and diazinon in six regions of Canada. Organochlorine (OC) pesticide use is related with an increase in cancer risk [12]. A positive association of pesticide exposure with Parkinson's disease (PD) was shown by [13]. Organochlorine (OC) pesticides are among the major types of pesticides, notorious for their high toxicity, their persistence in the physical environment and their ability to enter the food chain [14]. They tend to bioconcentrate and biomagnify in the food chains due to their stable structure and lipophilic character, particularly those associated with fatty tissues, leading to vertebrate and non-vertebrate toxicity in non-target organisms including humans [15]. Although the production and use of many types of OCs and organophosphorus (OPs) have been severely limited in many countries including Ghana, they are, nevertheless, still being used unofficially in large quantities in many parts of Ghana, and in other developing countries because of their effectiveness as pesticides and their relatively low cost [14].

[16] And [17] are few studies that have provided evidence of pesticide contamination in various environmental compartments in some rivers in Nigeria. Protecting Nigeria's fresh water bodies from pesticides and other pollutants is of outmost importance due to their prevailing toxicity even at trace levels. Thus, data pertaining to pesticide concentration in rivers and surrounding environments are very critical. Therefore this study aimed at determining the level of risk individuals living around river Gongola are exposed to.

\section{Material and methods}

\subsection{Study Site}

The research was carried out in River Gongola, situated at Yola, Adamawa state, Northeast Nigeria. It is located on the Benue River and has a population of 336,648 as at 2010. It is bounded by the coordinates 9०13'48” N 12²7'36" E. River Gongola is the principal tributary of the Benue river. The upper courses of the river are seasonal streams, but fill rapidly in August and September. The Gongola runs south to the Benue River, joining it to the opposite town of Numan.

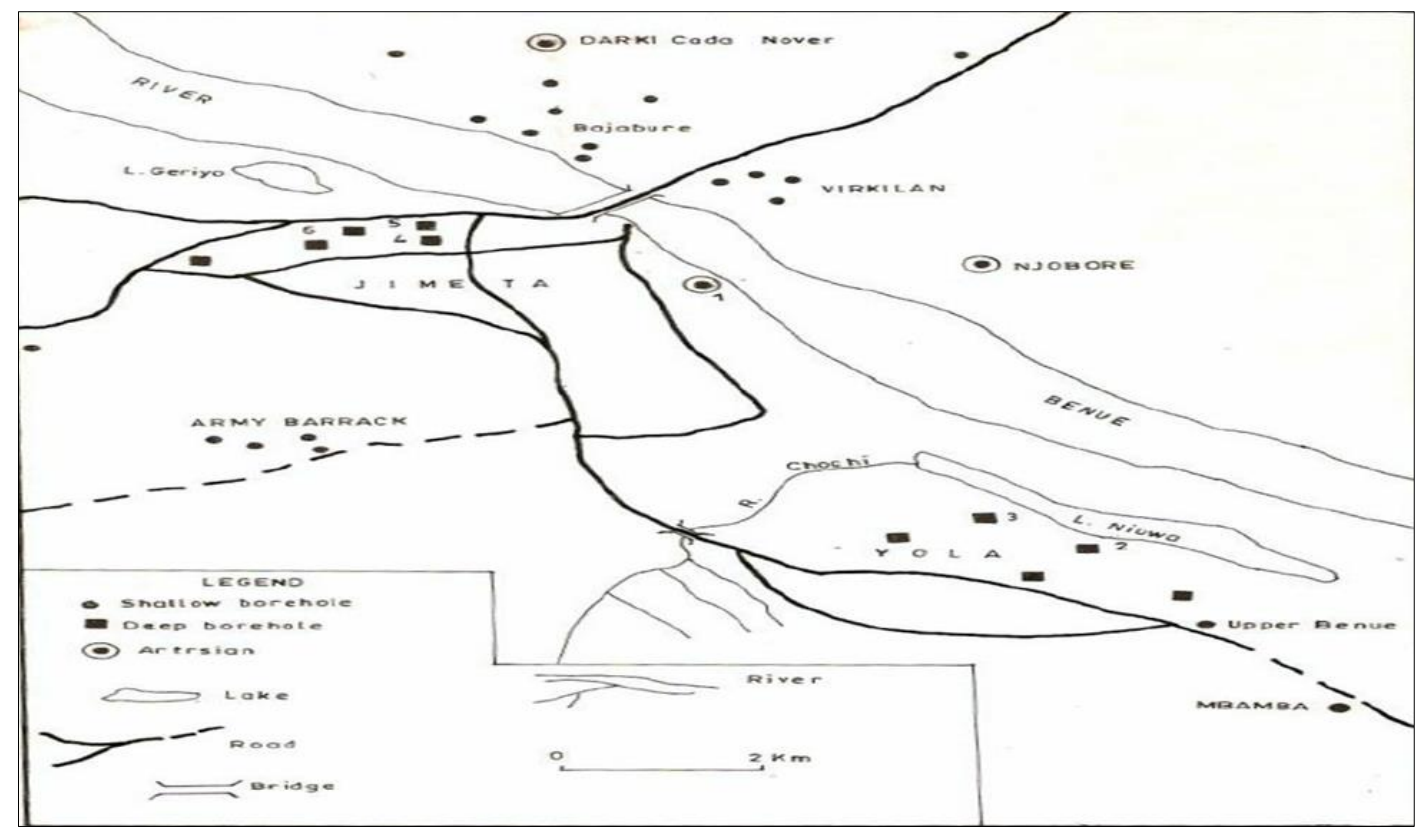

Figure 1The map of Yola showing the river Gongola (study site) 


\subsection{Sampling}

Samples which are representatives of the water bodies were collected and examined. Water samples were collected by lowering pre-cleaned plastic bottles into the bottom of the water body, $30 \mathrm{~cm}$ deep, and allowed to over flow before withdrawing. Ten (10) sampling points were used and the sampling points are approximately $50 \mathrm{~m}$ away from each other.

\subsection{Pesticide Residue Analysis}

Pesticide residue analysis was carried out using GC/MS after sample preparation.

\subsection{Preparation of Extraction Solvent}

A mixture of acetonitrile and n-hexane in the ratio of 1:20 was prepared with the aid of a measuring cylinder. The extraction solvent was prepared in a $1000 \mathrm{ml}$ beaker.

\subsection{Sample Extraction}

$100 \mathrm{ml}$ of water was measured out into a $250 \mathrm{ml}$ beaker and $30 \mathrm{ml}$ of the extraction solvent was added to it. After $48 \mathrm{hours}$, separating funnel method was used to extract the organic layer of the solvent. $1 \mathrm{ml}$ of the organic layer was stored in a sample bottle ready for GC/MS analysis.

\subsection{GC/MS Analysis and Conditions}

A gas chromatography from Agilent USA hypherated to a mass spectrophotometer (5975C) with triple axis detector equipped with an auto injector $(10 \mu$ l syringe) was used. Helium gas was used as a carrier gas. All chromatographic separation was performed on capillary column having specification: length; $30 \mathrm{~m}$, internal diameter 0.2 um, thickness; $250 \mu \mathrm{m}$, treated with phenyl methyl silox. Other GC-MS conditions are ion source temperature, $250^{\circ} \mathrm{C}$, internal temperature; $300^{\circ} \mathrm{C}$, pressure; $16.2 \mathrm{psia}$, out time, $1.8 \mathrm{~mm}, 1 \mu \mathrm{l}$ injector in split mode with split ratio $1: 50$ with injection temperature of $300^{\circ} \mathrm{C}$. $1 \mu \mathrm{l}$ of sample was injected. The condition temperature started at $35^{\circ} \mathrm{C}$ for $5 \mathrm{~min}$ and changed to $150^{\circ} \mathrm{C}$ at the rate of $4^{\circ} \mathrm{C} / \mathrm{min}$. The temperature was raised to $250^{\circ} \mathrm{C}$ at the rate of $20^{\circ} \mathrm{C} / \mathrm{min}$ and held for $5 \mathrm{mins}$. The total elution was $47.5 \mathrm{~min}$. MS solution software provided by supplier was used to control the system and to acquire the data; identification of the compounds was carried out by comparing the mass spectra obtained with those of the standard mass spectra from NIST library (NISTII).

\subsection{Health Risk Estimation}

The guidelines for potential health risk as drawn up by the US EPA were used to assess the risk of pesticides contained in each water sample on consumers. Estimated Average Daily Intake was obtained using the formula [18]:

$$
\text { EADI }=\frac{\text { Pesticideresidueinsample }\left(m \frac{g}{L}\right) X \text { Consumptionrateofwater }\left(\frac{L}{\text { day }}\right)}{\text { Bodyweight }}
$$

The consumption rate per capita of water from river gongola was estimated to be 120 liters per capita (0.70litres per individuals per day). This is based on the reviewed National Water and Sanitation Policy of the Federal Republic of Nigeria, 2004 [19]. The risk of exposure to a pesticide was estimated on the basis of the potential health risk index for noncarcinogenic chemicals according to [18] using the following formula:

$\mathrm{HRI}=\frac{E A D I}{A D I}$

Where HRI stands for health risk index, EDI stands for estimated daily intake, ADI stands for acceptable daily intake.

\subsection{Statistical Analysis}

Results obtained were subjected to Analysis of Variance (ANOVA) using SPSS (Statistical Package for Social Sciences) statistical software (version 21). Results were presented as Means \pm standard deviations. 


\section{Results}

\subsection{Pesticide Concentrations}

Nineteen (19) pesticide residues were detected in the samples of water analyzed (Table 1). Results of the analysis indicated the presence of organochlorine pesticides such as Dieldrin, Endrin, Fenthionsulfone, Linuron, phoratesulfone and Chlorpropham in concentrations ranging between $0.009 \mathrm{mg} / \mathrm{L}$ to $0.087 \mathrm{mg} / \mathrm{L}$. (Table 1 ). Dieldrin was detected in all sample points along the river gongola except at point 4. Endrin occurred in three sample points only while Fenthion sulfone was detected in only sample point 1 and 3 along the river with mean concentration of $0.005 \pm 0.01 \mathrm{mg} / \mathrm{L}$. Linuron, Phoratesulfone and chlorpropham have occurances of $60 \%, 50 \%$ and $50 \%$ respectively across all sample collection sites along the river. Organophosphate pesticide residues also detected include Biphenyl, Dichlorvos, Dichlobutrazole and Bromopropylate (Table 1). Biphenyl was detected in all sample collection points with a mean concentration of $0.015 \pm 0.003 \mathrm{mg} / \mathrm{L}$. Dichlorvos was detected in three sample collection sites as shown in the table 1 with a mean concentration of $0.012 \pm 0.001 \mathrm{mg} / \mathrm{L}$. Bromopropylate was found in only sample points 3 and 5 with a mean concentration of $0.018 \pm 0.002 \mathrm{mg} / \mathrm{L}$. Dichlobutrazole was detected across all sample collection points along the river with a mean of $0.025 \pm 0.006 \mathrm{mg} / \mathrm{L}$. Bupirimate and Entofenprox were among the pyrethroids detected. All pyrethroids occurred at concentrations within $0.003 \pm 0.001 \mathrm{mg} / \mathrm{L}$ and $0.500 \pm 0.10 \mathrm{mg} / \mathrm{L}$.

Table 1Concentrations of pesticide residues in water samples

\begin{tabular}{|c|c|c|c|c|c|}
\hline \multicolumn{6}{|c|}{ Concentrations of pesticide residues $(\mathrm{mg} / \mathrm{L})$} \\
\hline Pesticides & Point 1 & Point 2 & Point 3 & Point 4 & Point 5 \\
\hline Dieldrin & $0.012 \pm 0.021^{\mathrm{a}}$ & $0.023 \pm 0.010$ a & $0.011 \pm 0.012$ a & - & $0.023 \pm 0.012^{\mathrm{a}}$ \\
\hline Endrin & - & $0.012 \pm 0.021^{\mathrm{a}}$ & $0.013 \pm 0.001^{\mathrm{a}}$ & - & - \\
\hline Fenthionsulphone & $0.005 \pm 0.01$ a & - & $0.004 \pm 0.001^{\mathrm{a}}$ & - & - \\
\hline Linuron & $0.0245 \pm 0.02$ a & $0.025 \pm 0.007$ a & $0.015 \pm 0.009$ a & - & - \\
\hline Phoratesulfone & $0.009 \pm 0.002^{\mathrm{a}}$ & $0.004 \pm 0.001^{\mathrm{a}}$ & $0.009 \pm 0.003^{a}$ & - & $0.012 \pm .0014^{\mathrm{a}}$ \\
\hline Chlorpropham & $0.032 \pm 0.002^{\mathrm{a}}$ & $0.093 \pm 0.002^{\mathrm{a}}$ & $0.049 \pm 0.053^{\mathrm{a}}$ & - & $0.011 \pm 0.002^{\mathrm{a}}$ \\
\hline Thiometon & $0.035 \pm 0.026^{\mathrm{a}}$ & - & $0.014 \pm 0.007$ a & $0.012 \pm 0.002^{\mathrm{a}}$ & - \\
\hline Metalaxyl & $0.034 \pm 0.002^{\text {a }}$ & $0.011 \pm 0.001$ a & $0.023 \pm 0.004 \mathrm{a}$ & $0.065 \pm 0.02$ a & $0.092 \pm 0.002$ a \\
\hline Metobromuron & $0.067 \pm 0.07 \mathrm{a}$ & $0.169 \pm 0.004 \mathrm{a}$ & $0.217 \pm 0.003^{\mathrm{a}}$ & $0.119 \pm 0.001^{\mathrm{a}}$ & - \\
\hline Phosmet & - & - & $0.018 \pm 0.002^{\mathrm{a}}$ & - & $0.023 \pm 0.001^{\mathrm{a}}$ \\
\hline Dichlorvos & $0.012 \pm 0.001^{a}$ & $0.01 \pm 0.002^{a}$ & $0.021 \pm 0.002^{a}$ & - & - \\
\hline Dichlobutrazole & $0.043 \pm 0.002^{\mathrm{a}}$ & $0.015 \pm 0.005^{\mathrm{a}}$ & $0.025 \pm 0.006^{\mathrm{a}}$ & $0.025 \pm 0.002^{\mathrm{a}}$ & $0.03 \pm 0.002^{\mathrm{a}}$ \\
\hline Biphenyl & $0.031 \pm 0.31^{\mathrm{a}}$ & $0.012 \pm 0.002^{\mathrm{a}}$ & $0.015 \pm 0.003^{\mathrm{a}}$ & $0.01 \pm 0.004^{\mathrm{a}}$ & $0.16 \pm 0.002^{\mathrm{a}}$ \\
\hline Bromopropylate & - & - & $0.018 \pm 0.001^{\mathrm{a}}$ & - & $0.019 \pm 0.002^{\mathrm{a}}$ \\
\hline Vernolate & $0.007 \pm 0.001^{\mathrm{a}}$ & $0.084 \pm 0.007$ a & $0.105 \pm 0.003 \mathrm{a}$ & $0.095 \pm 0.021^{\mathrm{a}}$ & $0.023 \pm 0.002^{a}$ \\
\hline Etofenprox & $0.004 \pm 0.002^{\mathrm{a}}$ & $0.035 \pm 0.001^{\mathrm{a}}$ & $0.012 \pm 0.004^{\mathrm{a}}$ & $0.013 \pm 0.007^{\mathrm{a}}$ & - \\
\hline Carbozin & $0.0025 \pm 0.01^{\mathrm{a}}$ & $0.005 \pm 0.05^{\mathrm{a}}$ & - & - & - \\
\hline Bupirimate & $0.50 \pm 0.002 \mathrm{a}$ & - & - & - & $0.015 \pm 0.003 \mathrm{a}$ \\
\hline
\end{tabular}

Results represent mean \pm standard deviation of group pesticide residues obtained $(\mathrm{n}=2)$

Mean in the same row having the same letters of the alphabet are statistically non-significant $(\mathrm{p}>0.05)$.

The concentrations of the pesticide residues detected in the water samples occurred at concentrations below the maximum residue levels as shown in Table 2. However, most pesticide residues occurred at concentrations above the acceptable daily intake (ADI) as shown in Table 2. An exception is Biphenyl which was detected at concentrations of $0.16 \pm 0.002 \mathrm{mg} / \mathrm{kg}$, higher than the MRL and ADI, in sample point 5 . All pesticide residues detected were found to have maximum residue levels below their respective acceptable daily intake as set by FAO an EU. 
Table 2 Maximum residue levels and acceptable daily intake of pesticides detected in water samples

\begin{tabular}{|l|l|l|c|c|}
\hline Pesticides & Class & Type & MRL(mg/kg) & ADI(mg/kg) \\
\hline Dieldrin & Organochlorine & Insecticide & 0.100 & 0.0002 \\
\hline Endrin & Organochlorine & Insecticide & 0.100 & 0.0002 \\
\hline Fenthionsulphone & Organochlorine & Insecticide & 0.020 & 0.002 \\
\hline Linuron & Organochlorine & Insecticide & 0.200 & 0.003 \\
\hline Phoratesulfone & Organochlorine & Insecticide & 0.300 & 0.0005 \\
\hline Chlorpropham & Organochlorine & Insecticide & 0.005 & 0.005 \\
\hline Biphenyl & Organophosphate & Herbicide & 0.100 & 0.038 \\
\hline Metalaxyl & Organophosphate & Fungicide & 0.500 & 0.003 \\
\hline Metobromuron & Organophosphate & Herbicide & 0.010 & 0.008 \\
\hline Phosmet & Organophosphate & Herbicide & 0.010 & 0.010 \\
\hline Dichlorvos & Organophosphate & Insecticide & 0.100 & 0.004 \\
\hline Dichlobutrazole & Organophosphate & Fungicide & 0.010 & 0.021 \\
\hline Thiometon & Organophosphate & Insecticide & 0.050 & 0.005 \\
\hline Bromopropylate & Organophosphate & Herbicide & - & 0.030 \\
\hline Vernolate & Organophosphate & Herbicide & 0.010 & 0.050 \\
\hline Carboxin & Organophosphate & Herbicide & 0.010 & 0.008 \\
\hline Etofenprox & Pyrethroid & Insecticide & 0.001 & 0.030 \\
\hline Bupirimate & Pyrethroid & Fungi & 0.002 & 0.050 \\
\hline & & & \\
\hline
\end{tabular}

The mean MRL and ADI for Organochlorine pesticide residues in the analyzed water samples were $0.121 \pm 0.008$ and $0.002 \pm 008$ respectively. $0.08 \pm 0.002$ and $0.02 \pm 0.008$ respectively, for organophosphates and $0.002 \pm 0.0015$ and $0.04 \pm 0.006$ respectively for pyrethroids (Table 3 ). Concentrations of pesticide residues from the water samples are however, within this range.

Table 3 Average maximum residue levels ( $\mathrm{mg} / \mathrm{kg}$ ) and acceptable daily intakes (mg/kg) of the different class's pesticides

\begin{tabular}{|l|c|c|c|c|}
\hline Class of Pesticide & Total MRL & Total ADI & Average MRL & Average ADI \\
\hline Organochlorine & 0.725 & 0.012 & $0.121 \pm 0.008$ & $0.002 \pm 0.0008$ \\
\hline Organophosphate & 0.800 & 0.177 & $0.08 \pm 0.002$ & $0.02 \pm 0.008$ \\
\hline Pyrethroid & 0.003 & 0.080 & $0.002 \pm 0.0015$ & $0.04 \pm 0.006$ \\
\hline
\end{tabular}

\subsection{Estimated Daily Intake of each Pesticide Residue}

The table below (Table 4) shows the calculated estimated daily intake of each pesticide residue detected in the water samples analyzed. Values obtained ranges from $0.0001 \pm 0.001 \mathrm{mg} / \mathrm{L}$ to $0.002 \pm 0.002 \mathrm{mg} / \mathrm{L}$. Values for the calculated EDI were found to be below the acceptable daily intake for each pesticide. However, dieldrin, endrin and fenthionsulphone were observed to have EDI values greater than their respective ADI. This variation occurred at sample points 1,2 and 3 with EDI of $0.0003 \pm 0.002 \mathrm{mg} / \mathrm{L}, 0.0005 \pm 0.001 \mathrm{mg} / \mathrm{L}$ and $0.0003 \pm 0.002 \mathrm{mg} / \mathrm{L}$. 
Table 4 Calculated EDI across all sample points

\begin{tabular}{|c|c|c|c|c|c|}
\hline \multicolumn{6}{|c|}{ MEAN CALCULATED EDI OF DETECTED PESTICIDE RESIDUES (mg/L) } \\
\hline Pesticides & Point 1 & Point 2 & Point 3 & Point 4 & Point 5 \\
\hline Dieldrin & $0.0001 \pm 0.01^{\mathrm{a}}$ & $0.0003 \pm 0.01^{\mathrm{a}}$ & $0.0001 \pm 0.01^{\mathrm{a}}$ & - & $0.0002 \pm 0.02^{\mathrm{a}}$ \\
\hline Endrin & - & $0.0001 \pm 0.00$ a & $0.0003 \pm 0.01^{\mathrm{a}}$ & - & - \\
\hline Fenthionsulphone & $0.0005 \pm 0.01^{\mathrm{a}}$ & - & $0.0003 \pm 0.02^{\text {a }}$ & - & - \\
\hline Linuron & $0.0002 \pm 0.02^{\mathrm{a}}$ & $0.0001 \pm 0.02^{\mathrm{a}}$ & $0.0001 \pm 0.01^{\mathrm{a}}$ & - & - \\
\hline Phoratesulfone & $0.009 \pm 0.002^{\mathrm{a}}$ & $0.004 \pm 0.001^{\mathrm{a}}$ & $0.0002 \pm 0.03^{\mathrm{a}}$ & - & $0.0001 \pm .001^{\mathrm{a}}$ \\
\hline Chlorpropham & $0.0002 \pm 0.02^{\mathrm{a}}$ & $0.0001 \pm 0.00^{\mathrm{a}}$ & $0.0002 \pm 0.01^{\mathrm{a}}$ & - & $0.0001 \pm 0.02^{\mathrm{a}}$ \\
\hline Thiometon & $0.0003 \pm 0.02^{\mathrm{a}}$ & - & $0.0004 \pm 0.02^{\mathrm{a}}$ & $0.0001 \pm 0.02^{\mathrm{a}}$ & - \\
\hline Metalaxyl & $0.0002 \pm 0.02^{\mathrm{a}}$ & $0.0001 \pm .001^{\mathrm{a}}$ & $0.0003 \pm .004^{\mathrm{a}}$ & $0.0002 \pm 0.02^{\mathrm{a}}$ & $0.0001 \pm .002^{\mathrm{a}}$ \\
\hline Metobromuron & $0.0001 \pm 0.07 \mathrm{a}$ & $0.001 \pm 0.004^{\mathrm{a}}$ & $0.002 \pm 0.003^{a}$ & $0.001 \pm 0.001^{\mathrm{a}}$ & - \\
\hline Phosmet & - & - & $0.018 \pm 0.002^{\mathrm{a}}$ & - & $0.023 \pm 0.001^{\mathrm{a}}$ \\
\hline Dichlorvos & $0.0002 \pm .001^{a}$ & $0.0001 \pm .002^{\mathrm{a}}$ & $0.0002 \pm .002^{\mathrm{a}}$ & - & - \\
\hline Dichlobutrazole & $0.0003 \pm .002^{\mathrm{a}}$ & $0.001 \pm 0.002^{\mathrm{a}}$ & $0.0001 \pm .001^{\mathrm{a}}$ & $0.0001 \pm .002^{\mathrm{a}}$ & $0.0003 \pm .002^{\mathrm{a}}$ \\
\hline Biphenyl & $0.0001 \pm .001^{\mathrm{a}}$ & $0.0002 \pm .002^{\mathrm{a}}$ & $0.0001 \pm .003^{a}$ & $0.0001 \pm .004^{\mathrm{a}}$ & $0.0006 \pm .002^{\mathrm{a}}$ \\
\hline Bromopropylate & - & - & $0.0001 \pm .001^{\mathrm{a}}$ & - & $0.0007 \pm .002^{\mathrm{a}}$ \\
\hline Vernolate & $0.007 \pm 0.001^{\mathrm{a}}$ & $0.0004 \pm .007$ a & $0.0001 \pm .003^{a}$ & $0.0005 \pm .021^{\mathrm{a}}$ & $0.0003 \pm .002^{\mathrm{a}}$ \\
\hline Etofenprox & $0.0004 \pm .002^{\mathrm{a}}$ & $0.0003 \pm .001^{\mathrm{a}}$ & $0.012 \pm 0.004^{\mathrm{a}}$ & $0.013 \pm 0.007^{\mathrm{a}}$ & - \\
\hline Carbozin & $0.0005 \pm 0.01^{\mathrm{a}}$ & $0.0002 \pm 0.05^{\mathrm{a}}$ & - & - & - \\
\hline Bupirimate & $0.0006 \pm .002^{a}$ & - & - & - & $0.0002 \pm .003$ \\
\hline
\end{tabular}

\subsection{Health Risk Index}

The Health Risk Index (HRI) calculated for each pesticide residue analyzed is presented in Table 5 below. The HRI ranges from $0.01 \pm 0.001$ to $0.94 \pm 0.10$. These values are below one which indicates that life time consumption of water from river Gongola poses no significant health risk. An exception to this result is Dieldrin detected from sample collection point 3 with HRI of 3.20. Chlorpropham, Dichlorbutrazole, endrin and fenthionsulphone were found to have health risk index values close to 1 , an average value of $0.70 \pm 0.10$ 
Table 5 Calculated health risk index of each detected pesticide residue

\begin{tabular}{|c|c|c|c|c|c|}
\hline \multicolumn{6}{|c|}{ MEAN HRI OF PESTICIDE RESIDUES (mg/L) } \\
\hline Pesticides & Point 1 & Point 2 & Point 3 & Point 4 & Point 5 \\
\hline Dieldrin & $0.70 .021^{\mathrm{a}}$ & $3.20 \pm 0.010^{\text {a }}$ & $0.70 \pm 0.20^{\mathrm{a}}$ & - & $0.80 \pm 0.01^{\mathrm{a}}$ \\
\hline Endrin & - & $0.725 \pm 0.021^{\mathrm{a}}$ & $0.75 \pm 0.10^{\mathrm{a}}$ & - & - \\
\hline Fenthionsulphone & $0.65 \pm 0.01^{\mathrm{a}}$ & - & $0.76 \pm 0.01^{\mathrm{a}}$ & - & - \\
\hline Linuron & $0.10 \pm 0.08 \mathrm{a}$ & $0.35 \pm 0.07$ a & $0.07 \pm 0.002$ a & - & - \\
\hline Phoratesulfone & $0.29 \pm 0.02^{\mathrm{a}}$ & $0.94 \pm 0.01^{\mathrm{a}}$ & $0.29 \pm 0.03^{\mathrm{a}}$ & - & $0.20 \pm 0.01^{\mathrm{a}}$ \\
\hline Chlorpropham & $0.87 \pm 0.02^{\mathrm{a}}$ & $0.93 \pm 0.02^{\mathrm{a}}$ & $0.49 \pm 0.23^{\mathrm{a}}$ & - & $0.33 \pm 0.02^{\mathrm{a}}$ \\
\hline Thiometon & $0.14 \pm 0.02^{\mathrm{a}}$ & - & $0.05 \pm 0.007 \mathrm{a}$ & $0.45 \pm 0.02^{a}$ & - \\
\hline Metalaxyl & $0.09 \pm 0.02^{\mathrm{a}}$ & $0.07 \pm 0.01^{\mathrm{a}}$ & $0.03 \pm 0.004^{a}$ & $0.06 \pm 0.02^{\mathrm{a}}$ & $0.92 \pm 0.002^{\mathrm{a}}$ \\
\hline Metobromuron & $0.27 \pm 0.07$ a & $0.25 \pm 0.04 \mathrm{a}$ & $0.32 \pm 0.03 \mathrm{a}$ & $0.19 \pm 0.01^{\mathrm{a}}$ & - \\
\hline Phosmet & - & - & $0.21 \pm 0.02^{\mathrm{a}}$ & - & $0.03 \pm 0.001^{\mathrm{a}}$ \\
\hline Dichlorvos & $0.04 \pm 0.001^{\mathrm{a}}$ & $0.14 \pm 0.012^{a}$ & $0.09 \pm 0.002^{a}$ & - & - \\
\hline Dichlobutrazole & $0.43 \pm 0.02^{\mathrm{a}}$ & $0.75 \pm 0.05^{\mathrm{a}}$ & $0.25 \pm 0.04^{\mathrm{a}}$ & $0.54 \pm 0.02^{\mathrm{a}}$ & $0.30 \pm 0.02^{\mathrm{a}}$ \\
\hline Biphenyl & $0.03 \pm 0.07 \mathrm{a}$ & $0.05 \pm 0.02^{\mathrm{a}}$ & $0.05 \pm 0.003^{\mathrm{a}}$ & $0.03 \pm 0.004^{\mathrm{a}}$ & $0.50 \pm 0.02^{\mathrm{a}}$ \\
\hline Bromopropylate & - & - & $0.08 \pm 0.01^{\mathrm{a}}$ & - & $0.09 \pm 0.02 \mathrm{a}$ \\
\hline Vernolate & $0.03 \pm 0.01^{\mathrm{a}}$ & $0.84 \pm 0.07$ a & $0.10 \pm 0.03^{\mathrm{a}}$ & $0.13 \pm 0.07^{a}$ & $0.03 \pm 0.002^{\mathrm{a}}$ \\
\hline Etofenprox & $0.04 \pm 0.02^{\mathrm{a}}$ & $0.02 \pm 0.01^{\mathrm{a}}$ & $0.07 \pm 0.04^{\mathrm{a}}$ & $0.04 \pm 0.07^{a}$ & - \\
\hline Carbozin & $0.12 \pm 0.01^{\mathrm{a}}$ & $0.10 \pm 0.05^{\mathrm{a}}$ & - & - & - \\
\hline Bupirimate & $0.10 \pm 0.02^{\mathrm{a}}$ & - & - & - & $0.03 \pm 0.03 \mathrm{a}$ \\
\hline
\end{tabular}

\section{Discussion}

River Gongola is widely used as a source of drinking water for majority of the populace living around Yola. Pesticides have become ubiquitous contaminants and implicated in a broad range of deleterious health effects in laboratory animals and man [15]. Hence, the detection of any of its residues in water or any other food media could cause potential health problems when they occur at concentrations above the maximum residue level (MRL) and acceptable daily intake (ADI). Results of this study revealed the presence of a broad range of pesticide residues in samples of water collected from different sample sites. Among the residues detected are banned pesticides such as organochlorines. Other classes of pesticide detected are the organophosphate and pyrethroids.

The concentrations of the pesticide residues detected in the water samples occurred at concentrations below the maximum residue levels as shown in Table 1 . However, most pesticide residues occurred at concentrations above the acceptable daily intake (ADI). This defines to a certain degree, the level of risk associated with the consumption of water from river Gongola. This result is however not in tandem with the findings of [5] and also does not correspond with the findings of [15]. Dieldrin and Endrin occurred at a mean concentration of $0.027 \pm 0.01 \mathrm{mg} / \mathrm{L}$ and $0.013 \pm 0.002 \mathrm{mg} / \mathrm{L}$ respectively. These concentrations are below the MRL $(0.10 \mathrm{mg} / \mathrm{L}$ for both pesticide residue) but above their respective ADI $(0.0002 \mathrm{mg} / \mathrm{L}$ for both pesticide residue). However, the estimated daily intake (EDI) of these pesticides was found to be below the acceptable daily intake (ADI) and thus have HRI values of $(3.20 \pm 0.12$ and $0.70 \pm 0.01$ for dieldrin and a mean of $0.70 \pm 0.12$ for endrin). Only dieldrin from sample collection point 2 along the river was found to have a HRI above 1 which implies significant health risk.

Fenthionsulphone, Linuron and Phoratesulphone were the other organochlorine pesticide residues detected in analyzed water sample with mean concentrations of $0.009 \pm 0.001 \mathrm{mg} / \mathrm{L}, 0.067 \pm 0.02 \mathrm{mg} / \mathrm{L}$ and $0.031 \pm 0.02 \mathrm{mg} / \mathrm{L}$ 
respectively. These concentrations were found to be below MRL of the respective pesticides. The calculated estimated daily intake (EDI) of the respective pesticides was also found within safe ADI limits. Hence, the calculated health risk index (HRI) of the respective pesticide were below 1 and thus long time consumption of water samples containing these pesticides poses no significant risk. However, organochlorine pesticides such as Dieldrin and Endrin have been banned [6].

Since organophosphorus pesticides are degraded very quickly [14], and the samples have been collected randomly, the concentration of organophosphorus pesticides (prior to the collection) may be more than the detected residue value. Organophosphate pesticide residues detected in this study includes Biphenyl, Dichlorvos, Dichlobutrazole and Bromopropylate. The calculated estimated daily intake (EDI) of these pesticide residues were found to be within the range $0.00014 \pm 0.001 \mathrm{mg} / \mathrm{L}$ to $0.00093 \pm 0.0002 \mathrm{mg} / \mathrm{L}$. These values were below the acceptable daily intake (ADI) of water and hence the health risk index (HRI) associated with these pesticide residues were calculated to be within the range $0.003 \pm 0.001$ to $0.23 \pm 0.02$. Therefore the risk associated with the consumption of water contaminated with these pesticides is rather low. Biphenyl detected in sample point 5 is the only pesticide residue which does not follow this trend as its concentration $(0.16 \pm 0.002 \mathrm{mg} / \mathrm{kg})$ was found to be higher than the MRL and ADI which corresponds with the findings of [15], hence poses a significant risk to health. Prolonged consumption of these pesticides through food can be stored in the lipid of human body and may cause severe health hazards [14].

Entofenprox (an insecticide) and Bumpirimate (a fungicide) were the only pyrethroids that were detected in water samples from river Gongola. The pesticide residues occurred at mean concentrations of $0.015 \pm 0.001 \mathrm{mg} / \mathrm{L}$ and $0.176 \pm 0.13 \mathrm{mg} / \mathrm{L}$ above respective MRL of $0.001 \mathrm{mg} / \mathrm{L}$ and $0.002 \mathrm{mg} / \mathrm{L}$. Calculated EDI of each pesticide residue were, however, found to be within the acceptable daily intake of each pesticide, thus the mean HRI associated with the respective pesticide residues were $0.02 \pm 0.001$ and $0.03 \pm 0.01$, less than one. Therefore, the risk associated with the consumption of water contaminated by these pesticides is rather low.

\section{Conclusion}

From this study, the concentrations of the pesticide residues detected in the water samples occurred at concentrations below the maximum residue levels. However, most pesticide residues occurred at concentrations above the acceptable daily intake (ADI). This defines, to a certain degree, the level of risk associated with the consumption of water from river Gongola. The health risk index of most pesticide residues occurred below 1 and thus life time consumption of water containing this pesticide poses no significant risk. However, the presence of banned organochlorine pesticide residues suggests their use in agricultural activities.

\section{Compliance with ethical standards}

\section{Acknowledgments}

We want to express our thanks to Professor Otitoju Olawale, the Laboratory head, for his unwavering support and guidance, and all those who contributed directly to this study.

\section{Disclosure of conflict of interest}

The authors state that there was no conflict of interest.

\section{Statement of informed consent}

Informed consent was obtained from all individual participants included in the study.

\section{References}

[1] Sankaramakrishnan N, Sharma AK, Sanghi R. Organochlorine and Organophosphorus pesticide residues in ground water and surface water of Kanpur, Uttar, Pradesh, India. Environment International. 2005; 31: 113-120.

[2] Thurman EM, Bastian KC, Mollhagan T. Occurrence of Cotton Herbicides and Insecticides in Playa Lakes of High Plain and West Texas. Sci. Total Environ.2000; 248 (2-3): 89-200.

[3] Joseph CK, Naomi B, Maimuna W, Musa MM. Organochlorine, Organophosphorus and Pyrethroid Pesticides Residues in Water and Sediment Samples from River Benue in Vinikilang, Yola, Adamawa State, 
Nigeria Using Gas Chromatography-Mass Spectrometry Equipped with Electron Capture Detector. American Journal of Environmental Protection. 2015; 3(5): 164-173.

[4] Agarwal SK. Pesticides Pollution. A.P.H. Publishing Corporation, New Delhi-110002. 2009; 23-67.

[5] Abah MA, Otitoju 0, Okoli EC, Ozioma PE, Bando DC, Zephaniah HS. Determination of selected pesticide residues in leafy vegetables (Amaranthusspinosus) consumed in Donga, Taraba state. International Journal of Biochemistry, Bioinformatics and Biotechnology Studies. 2021; 6(2): 9-16.

[6] Okoli EC, Otitoju O, Abah MA, Ozioma PE, Bando DC, Zephaniah HS. Ecological risk assessment of pesticide residues in fish samples from river donga in Donga, Taraba state, nigeria. International Journal of Biochemistry, Bioinformatics and Biotechnology Studies. 2021; 6(2): 1-8.

[7] Rahman MM. Pesticides: their uses and problems in context of Bangladesh. In: Proceedings of the national workshop on conventional and nuclear technique for pesticide residues studies in food and environment at IFRB, Savar. 2000; 1-25.

[8] Otitoju 0, Onwurah INE. Glutathione S-transferase (GST) activity as a biomarker in ecological risk assessment of pesticide contaminated environment, African Journal of Biotechnology. 2007; 6(12): 1455-1459.

[9] Recio R, Robbins WA, Borja-Aburto V, Moran-Martinez J, Froines JR, Hernandez RM, Cebrian ME. Organophosphorus pesticide exposure increases the frequency of sperm sex null aneuploidy. Environmental Health Perspective. 2002; 109(12): 1237.

[10] Lee W, Blair A, Hoppin J, Lubin J, Rusiecki J, Sandler D, Dosemeci M, Ala- vanja M. Cancer incidence among pesticide applicators exposed to chlorpyrifos in the agricultural health study. J Natl Cancer Inst. 2004; 96(23): 1781-1789.

[11] Pahwa P, Karunanayake CP, Dosman JA, Spinelli JJ, McLaughlin JR. Soft-tissue sarcoma and pesticides exposure in men: results of a Canadian case-control study. Journal of Occupational Environmental Medicine. 2011; 53(11): 1279-1286.

[12] Xu X, Dailey A, Talbott E, Ilacqua V, Kearney G, Asal N. Associations of serum concentrations of organochlorine pesticides with breast cancer and prostate cancer in US adults. Environmental Health Perspective. 2010; 118(1): 60-66.

[13] Hancock DB, Martin ER, Mayhew GM, Stajich JM, Jewett R, Stacy MA, Scott WK.Pesticide exposure and risk of Parkinson's disease: a family-based case-control study.BMC Neurology. 2008; 8(1): 6.

[14] Ntow WJ. Organochlorine pesticides. Archives of Environmental Contamination and Toxicology. 2001; 40: 557563.

[15] Otitoju O, Abah MA, Otitoju GT, Yale FB, Okoli EC, Habibu B. Risk Assessment of Pesticide Residues in Soil Samples along River Gongola, Adamawa State. International Journal of Research Publication and Reviews. 2022; 3(1): 214-218.

[16] AdeboyejoOA, Clarke EO, OlarinmoyeMO. Organochlorine pesticide residues in water, sediments, fin and shellfish samples from lagos lagoon complex, Nigeria. Researcher. 2011; 3: 38-45.

[17] Adeyemi D, Anyakora C, Ukpo G, Adedayo A, Darko G. Evaluation of the levels of organochlorine pesticide residues in water samples of Lagos lagoon using solid phase extraction method. Journal of Environmental Chemistry and Ecotoxicology. 2011;3: 160-166.

[18] Fianko RJ, Augustine D, Samuel TL, Paul OY, Eric TG, Theodosia A, Augustine F. Health Risk Associated with pesticide contamination in Ghana. Journal of Environmental Protection. 2011; 2: 115-123.

[19] Abdulrahman A, Abdullahi A. Risk situations and poverty management strategies among rice farmers inNiger state, Nigeria. Journal of Sustainable Development in Africa. 2020; 22(4): 61-73.

[20] FAO, WHO.Pesticide residues in food 2019 - Joint FAO/WHO Meeting on Pesticide Residues Evaluation Part I: Residues. Rome. 2020. 